experience, on July 23,1834 he addressed a letter to the Editor of the Philosophical Magazine entitled "Caution to Experimenters with the Electrical Kite". A day or two previously, when clouds had begun to gather, he had gone to the Artillery Barracks ground with an electric kite, got it afloat letting out string through his hands from a coil thrown on the ground. "When about a hundred yards of the string had been lot out," he says, "a tremendous discharge took place, which gave me such a blow in the chest and leg that I became completely stunned, let go the string and consequently the kite soon fell." Sturgeon blamed himself for the accident, and after explaining the precautions which should be taken concluded "young persons who are fond of kite flying should also be cautious not to have their kites up during thunder storms, as it is possible that a wet string may transmit a violent discharge, from which a serious accident may occur."

\section{Whewell on Inductive Science}

When Whewell held the chair of mineralogy at Cambridge, he planned a series of treatises on the progress of knowledge. When considering the method of dealing with his subject, he corresponded with the political economist, the Rev. Richard Jones (17901855) and in a letter dated July 27, 1834, said : "You are to understand that I am to consist of three Books. Book I History of Inductive Science, namely, Astronomy, Mechanics, Physics, Chemistry and Botany historiographized in a new and philosophical manner. Book 2 Philosophy of Inductive Science, which is what I want to shew you. It will be dry and hard, I fear, as it must contain most of the metaphysical discussions which have been alluded to of late, but it must also contain all the analysis of the nature of Induction and the Rules of its exercise, including Bacon's suggestions. Book 3 Prospects of Inductive Science. The question of the possibility and method of Applying Inductive processes as illustrated in the philosophy of Book 2, to other than material sciences ; as philology, art, politics and morals."

\section{Launch of H.M.S. Pique}

On July 28, 1834, the Times recorded the launch at Plymouth of H.M. Frigate Pique, 36 guns. The surveyor, or chief constructor, of the Navy was then Captain (afterwards Admiral Sir William) Symonds (1782-1856) who had been appointed to the post in 1832 in succession to Sir Robert Seppings. The Pique, said the Times, was built upon the plan of Captain Symonds, "who has now, we believe, had the construction of ten ships of war upon his fundamental principles, as a naval architect-that great breadth imparts to a vessel greater stability, or a capability of sustaining an inclined force at the least angle of inclination. This position must be undoubtedly true; but it is contended that its development has been carried to a degree of extravagance from which no desirable advantage whatever has been experienced, while the expense has been enormous... . The dimensions of the Pique are length of lower deck, 160 feet, breadth extreme 44 feet, depth of hold 13 feet 9 inches, tonnage 1,400 tons. She has been constructed under the able directions of Thomas Roberts, Esq., the veteran ship-builder of Plymouth dockyard, who has now completed the 50th man-of-war launched since his advancement to his present honourable rank."

\section{Societies and Academies}

LONDON

Mineralogical Society, June 7. C. PaLACHE : The form relations of the lead oxychlorides, laurionite, paralaurionite, and fiedlerite. The separate identity of each of the first two minerals is confirmed and their homoeomorphism is exhibited by a re-orientation of laurionite. The form series of fiedlerite has been simplified by the choice of a new unit form. New forms are described on paralaurionite and fiedlerite. The crystallography of all three species is summarised in new angle-tables, and their habits are illustrated by a series of drawings. F. A. Bannister : The crystal structure and optical properties of matlockite $(\mathrm{PbFCl})$ : W. Nieuwenkamp's recent work proving the identity of matlockite with artificial lead fluochloride, $\mathrm{PbFCl}$, has been confirmed. New chemical analyses, $\mathrm{X}$-ray work and optical measurements have been carried out on single crystals of matlockite from Cromford, Derbyshire. Single crystal photographs of the mineral have also confirmed the crystal structure proposed for artificial $\mathrm{PbFCl}$. Artificial $\mathrm{BiOCl}, \mathrm{BiOBr}$ and $\mathrm{BiOI}$ have crystal structures of the same type, and the relationship between matlockite and these and other compounds is discussed. Artificial $\mathrm{Pb}_{2} \mathrm{OCl}_{2}$ has a crystal structure quite different from that of matlockite. Mendipite, $\mathrm{Pb}_{3} \mathrm{O}_{2} \mathrm{Cl}_{2}$, contains no fluorine, and it is improbable that fluorine has been overlooked in the oxychloride minerals from Laurium, Greece. V. ZsIvnY and L. ZомвоRY: Berthierite from Kisbánya, Carpathians. This rare mineral, previously known from two localities in old Hungary, is now described from a third, namely Kisbánya in comitat Szatmár (now Chiuzbaia in Satu Mare, Roumania) where it occurs as bundles of needles with stibnite and rhombohedral carbonates. Analysis agrees closely with the formula $\mathrm{FeS} . \mathrm{Sb}_{2} \mathrm{~S}_{3}$, but the specific gravity 4.65 is much higher than values previously recorded. L. J. SPENCER : Beryllium minerals (euclase and phenakite) from Africa. Apart from beryl, there are very few recorded occurrences of beryllium minerals in the whole of Africa. Euclase is described from pegmatite on the Lukangasi mica claim, Morogoro district, Tanganyika Territory. The main crystal on the single specimen collected measures $7 \cdot 2 \mathrm{~cm}$. by $3.5 \mathrm{~cm}$., being much larger than any euclase crystal hitherto known. Seventeen crystal forms were determined. Small erystals of phenakite from pegmatite at the Klein Spitzkopje, South-West Africa, are of two distinct habits, prismatic and lenticular. A. C. Skerr and F. A. BANNISTer : Lusakite, a cobalt-bearing silicate from Northern Rhodesia. The mineral occurs embedded in quartzmagnetite-kyanite-rock of gneissoid appearance from 80 miles east of Lusaka. Crystals, generally tabular to $(010)$ varying up to $5 \mathrm{~mm}$. in length, are black in hand-specimens, but show a deep cobelt-blue colour, and strong pleochroism in thin section. The mean refractive index is approximately 1.74 and $2 \mathrm{~V}$ is near $90^{\circ}$. Oscillation, Laue, and rotation photographs show that lusakite has an orthorhombic unit cell with edges $a 7 \cdot 86, b 16 \cdot 62, c 5 \cdot 63 \mathrm{~A}$., and space-group $V_{h}{ }^{17}$. The unit cell contains 8 [RO. $\left.\mathrm{Al}_{2} \mathrm{SiO}_{8}\right]$ where $\mathrm{R}$ represents $\mathrm{Fe}, \mathrm{Co}, \mathrm{Ni}, \mathrm{Mg}, \mathrm{Al}$, and $\mathrm{H}$. The cobalt content is unique for a silicate and reaches $8 \frac{1}{2}$ per cent $\mathrm{CoO}$, or nearly two atoms of cobalt per unit cell. It is almost identical in physical properties with staurolite, and $\mathrm{X}$-ray photographs show that it possesses the same type of crystal strueture. A. W. Groves : The 
determination of small amounts of copper in rocks. The paper describes the application to silicate analysis of the sodium diethyl-dithio-carbamate colorimetric method for copper. Data on the retention of copper by the ammonia precipitate are given. The method has a range of $0 \cdot 001-0.25$ per cent $\mathrm{CuO}$ when a sample of 2 grams is used. L. J. SPENCER : Thirteenth list of new mineral names. A dictionary list of 112 names collected from the literature of the past three years. Since the first list in 1897, a total of 1,918 names has been collected. L. J. SPENCER : A new meteoric stone from Silverton, New South Wales. A beautifully oriented stone weighing 351 grams was found by Mr. R. Bedford amongst debris in the old museum at Port Adelaide, which has recently been reorganised as a Nautical Museum. It probably dates from the time (1883) of the discovery of the rich mineral deposits at Broken Hill in the Silverton district. The stone is a white hyperstheneolivine-chondrite of the Baroti type with only little nickel-iron. M. H. Hey : Studies on the zeolites (8). A theory of the vapour-pressure of zeolites. An equation for the water vapour pressure of a zeolite (or other compound showing similar dissociation phenomena) is derived on simple kinetic grounds, and is shown to agree reasonably well with the available experimental data. The equation, which can only be a first approximation to the truth, is compared with other equations previously proposed. Kinetic treatment also leads to a reasonable equation for the rate of diffusion of water within a zeolite crystal. The condition of the water in the zeolites is discussed.

\section{EDINBURGH}

Royal Society, June 4. H. BRIGGS : (1) Graphical classification of carbonaceous minerals : the mineral oils. The graphical method adopted in previous papers relating to the evolution of carbonaceous minerals is extended to oils. The inclusion of mineral resins indicates their connexion with the heavy and light crude oils. The 'development lines' for the oils eventually merge with the coal belt at the stage of the lignites, thus supporting the view that coal and oil were derived from similar raw material, but by divergent courses of chemical evolution. Bischof's hypothesis to the effect that "the most dissimilar substances may be produced from ligneous fibre, according to the nature of the change" is thus revived. (2) Products of the natural development of coal and oil. The products of the maturing process, water, methane and carbon dioxide, are discharged in vary. ing proportions during different stages of the evolution. Equations are constructed connecting the amount of these compounds, the slope of the 'development line' of the fuel, and the loss in weight during the transformation, with the percentages of oxygen at the beginning and end of the phase. Obtaining loss of weight from field and other sources, the equations are solved and the discharges of water, methane and carbon dioxide ascertained. The derivation of anthracite from semi-bituminous coal requires the consumption instead of the discharge of water. Also the generation of oil from vegetable matter involves the appearance of water on the lefthand side of the equation. Marx G. Calderr: Notes on the Kidston collection of fossil plant slides. (5) Structure of two Lower Carboniferous Lepidodendroid stems, one of the Lepidophloios Wünschianus type, and the other of the Lepidodendron fuliginosum type. The anatomy of two Scottish Carboniferous Limestone stems, labelled by Kidston as a new species "Lepidodendron Langi", is described. One stem, from Cadder, is referred to Lepidophloios Wïnschianus, Carruthers sp.: the other, from Carluke, is referred to Lepidodendron fuliginosum, Williamson, and is discussed in relation to the British Carboniferous 'plant-break'. (6) Structure of two Lepidodendroid stems from the Carboniferous flora of Berwickshire. Two species of Lepidodendron from Calciferous Sandstone rocks in Berwickshire are discussed. One of them, to which Kidston had given the MS name of "Lepidodendron Macconochiei", is referred to Lepidodendron brevifolium, Williamson : and the other is referred to Lepidodendron sp. JESSIE A. R. Wrison : A new species of Psygmophyllum from the Upper Carboniferous of Scotland. A new species of Psygmophyllum from the Upper Carboniferous of Scotland is described and figured. The material upon which this new species is founded was discovered in Coal Measure shales exposed in the bank of the River Nethan, near Crossford, Lanarkshire, Scotland, and consists of two slabs of shale bearing four isolated leaf-impressions. These leaves measure about $5 \mathrm{~cm}$. in length and show a single bifurcation of the lamina. This new species, the first record of a Psygmophyllum from the Carboniferous rocks of Scotland, has been named Psygmophyllum scoticum. J.S. HUNTER : The photoelectric thresholds of some turned metallic surfaces. Long wave-length photoelectric thresholds have been determined for the turned surfaces of the metals copper, silver, antimony, bismuth, tin, lead, nickel, iron, zinc, aluminium, brass and cast steel. These thresholds are found to be at 2985 A., 3200 A., 2996 A., 3075 A., 3000 A., 3060 A., 3125 A., 2980 A., 3225 A., 3740 A., 3025 A., and 2916 A. respectively. The photoelectric currents were measured by a valve electrometer circuit. The above thresholds are found to approximate to those for the same metals in the partially out-gassed state. It is concluded that a turned surface is one which is partially denuded of occluded gases. Robert SchIAPP : Note on the electron configurations $p^{2} s, p^{4} s$. The secular equations for the energy-levels of these configurations, inclusive of orbit-spin interaction, are set up by treating the electrostatie exchange energy of two electrons as formally equivalent to a magnetic coupling between their spins (Dirac, Van Vleck). The equations are expressed in terms of three parameters, giving respectively the coupling between the equivalent electrons, the coupling between the $s$ electron and the core, and the orbit-spin coupling. The $g$-values are found as functions of these parameters. The levels are compared with those observed in As I, agreement being reasonably good.

\section{Paris}

Academy of Sciences, May 28 (C.R., 198, 1889-1952). A. Cotton and Tsaï Belling : The magnetic double refraction of oxygen and nitrogen in the gaseous state and of aqueous solutions of chlorates. These experiments were carried out with the Bellevue magnet, with the addition of a supplementary coil. Pifrre WeIss : The variation of saturation magnetisation at low temperatures. The $T^{3 / 2}$ law. The $T^{2}$ law proposed by Weiss and Forrer expresses the experimental figures for iron and nickel down to $90^{\circ} \mathrm{K}$., but below that temperature the $T^{3 / 2}$ law appears to agree better with the measurements. Bertrand Gambier : Tetrahedra conjugated to a quadric $\boldsymbol{\Sigma}$ and to tangent edges of a quadric $S$. Tetrahedra of which the edges are tangent to two 
quadrics $S, S^{\prime}$. Plerre Boos : A characteristic property of surfaces of revolution. K. NIKolsKY : The equation of the photon. ROBERT ForRer and Mrle. A. Serres: A new magnetic phenomenon : increasing paramagnetism superposed on diamag netism in alloys with a false Curie point. Nicolas Perakis and Lfandre Capatos: The magnetochemistry of rhenium. Metallic rhenium and heptavalent rhenium. RENE AUDUBERT and JEAN ROULLEAU: The influence of polarisation on the effects of electrolytic selenium photocells. P. JACQUET : The adherence of electrolytic deposits of copper. M. GuInlot and M. Haissinsky : The reduction of polonium in solution. A. MrCHEL and G. Chaudron : The transformations of pyrrhotine and of ferrous sulphide. P. GoldFinger and $L$. SCHEEPERS: A micromethod for the determination of heavy water. The construction and mode of use of a float is described by means of which densities on $0 \cdot 1-0 \cdot 2$ c.c. of liquid can be determined with an accuracy of one unit in the fifth place. JEAN BUREAU : The diagram sodium nitrite, water. The hydrate $\mathrm{NaNO}_{2} \cdot 0 \cdot 5 \mathrm{H}_{2} \mathrm{O}$. F. BourIoN and MLLe. O. HuN : The determination of the total hydration of the ions of potassium bromide. A. BouzAt and M. ScHMITT : The determination of azeotropic compositions. The azeotropes of benzene and cyclohexane. P. LAFFITTE and P. GRANDADAM : The direct oxidation of platinum under pressure. Platinum black, heated in oxygen under a pressure of 40 atmospheres, fixes the maximum proportion of oxygen at temperatures between $450^{\circ}$ and $460^{\circ} \mathrm{C}$. At higher pressures there are indications of the formation of mixtures of $\mathrm{PtO}$ and $\mathrm{PtO}_{2}$ : the latter has been isolated. B. BocircH : Some properties of silver silicate. The yellow colorations of glass produced by silver are probably due to the formation of silver silicates, R. DELAvautT : The mechanism of the oxidation of magnesium alloys at a high temperature. When the magnesium contains ten per cent or less of foreign constituents, the oxidation of the heterogeneous metal starts through a liquid phase showing protuberances offering a large surface of contact with the air. OCTAVE BAILLY and JACQUES GAUMÉ : An unexpected mode of formation of the monoester of $\beta$-glycerophosphoric acid. RENÉ TruCheT and JeAN CHAPRON : The Raman spectrum of conjugated double links in a nucleus. The Raman spectra of cyclopentadiene and dicyclopentadiene are given. Cyclopentadiene resembles furane, pyrrol and thiophene in giving a strong Raman line at 1400 $1500 \mathrm{~cm}^{-1}$. From this it is concluded that the existence of the 1580 line for benzene furnishes no argument for rejecting the Kékulé formula. J. Flandrin and G. LUCAS: The age of the deposits with Medjanian facies of Djebel Morissane (Department of Constantine). Nrcoras Théobald : The fossil insects of Kleinkembs (Pays de Bade). A study of about 1,000 specimens collected by Mieg and presented to the Basle Natural History Museum. AxpHonse LabBé : The obscure penial gland of the Silicoderms. MME. LUCIE RandoIN and MLLE. SuzanNe Queuille: Can the evolution of A avitaminosis be influenced by the nature and proportions of the proteins of the basic regime? RENÉ HAZARD : Some physiological actions of sarothamnine and genisteine. W. KopACZEWŚs I : The rôle of the physical factors in the lacto-gelification of serum. MME. N. Dobrovolskara-Zavadskara and P. ZÉPhIROFF : A substance isolated from adenocarcinoma of the udder of mice, capable of activating the growth and advancing genital development in young rats.

\section{Official Publications Received}

Great Britain and Ireland

British Non-Ferrous Metals Research Association. Fourteenth Annual Report and Notes on Researches in Progress for the Year ending December 31st, 1933. Pp. 48. (London.)

Department of Scientiflc and Industrial Research. Report of the Radio Research Board for the period 1st January 1932 to 30th September 1933. Pp. iv $+137+4$ plates. (London: H.M. Stationery fifice.) 28. $6 d$. net.

British Science Guild. The Annual Report of the Council of Management, 1933-1934, presented at the Annual General Meeting held at the Royal Society of Arts, London, on Tuesday, 12th June 1934. Pp. 31. (London.) 18.

Papers of the Greenock Philosophical Society. Britain's Coa Problems: being the Watt Anniversary Lecture for 1934 delivered before the Society on 2nd March 1934. By Prof. William A. Bone. Pp. 30. (Greenock.)

Department of Scientific and Industrial Research. Summary of Progress of the Geological Survey of Great Britain and the Museum
of Practical Geology for the Year 1933. Part 2. Pp. iv $+108+8$ plates. (London: H.M. Stationery Office.) 38. net

Empire Cotton Growing Corporation. Report of the Administrative Council of the Corporation submitted to the Thirteenth Annua General Meeting on June 14th, 1934. Pp. if +72. (London.)

The Royal Society for the Protection of Birds. Forty-third Annua Report, January 1st to December 31st, 1933; with Proceedings of Annual Meeting 1934. Pp. 54. (London.)

Joint Board of Research for Mental Disease : City and University of Birmingham Annual Report, 1933-1934. Pp. 14 (Birmingham. Miniatry of Agriculture and Fisheries. Guide to the Licensing of Bulls in England and Wales. Pp. 15. (London: Ministry of Agriculture and Fisheries.)

OThER COUNTRIES

Bulletin of the Madras Government Museum. New Seried, Genera Section, Vol. 1, Part 3: Tiruparuttikunram and its Temples, with Appendices on Jaina Units of Measurement and Time, Cosmology and plates. (Madras: Government Press.) 11.4 rupees.

Commonwealth of Australia : Council for Scientific and Industria Research. Catalogue of the Scientific and Technical Periodicals in the Libraries of Australia. Supplement 1928-1933. Edited by C. A. for Scientiflc and Industrial Research.) 58

Records of the Indian Museum. Vol. 36, Part 1: Notes on Fishes in the Indian Museum. 22: On a Collection of Fish from the S. Shan States and the Pegu Yomas, Burma. By
Dev Mukerji. Pp. 123-138. (Calcutta.)

Memoirs of the Geological Survey of India. Vol. 64, Part 2: Asbestos in the Ceded Districts of the Madras Presidency, with Notes on it Occurrence in other Parts of India. By Dr. A. L, Coulson. Pp. vii + $143-266+x x+$ plates $6-10$. (Calcutta.) 3.8 rupees; $6 s$.

Commonwealth of Australia : Council for Scientiflc and Industrial dietin No. 79: The Lucerne Flea" Smynthurus viridis (Melbourne : Government Printer.)

Smithsonian Miscellaneous Collections. Vol. 89, No. 15 : World Weather and Solar Activity. By H. Helm Clayton. (Publication 3245.) Pp. 52. Vol. 91, No. 2: Reports on the Collections obtained 3245.) Pp. 52. Vol. 91, No. 2: Reports on the Collections obtained
by the First Johnson-Smithsonian Deep-Sea Expedition to the Puerto by the First Johnson-Smithsonian Deep-Sea Expedition to the Puerto
Rican Deep-New Mollusks of the Family Turritidæ. By Paul Rican Deep-New Mollusks of the Family Turritidæ. By Paul
Bartsch. (Publication 3229.) Pp. 29+8 plates. Vol. 91, No. 12: Bartach. (Publication 3229.) Pp. 29+8 plates. Vol. 91, No. 12:
Reports on the Collections obtained by the First Johnson-Smithsonian Reports on the Collections obtained by the First Johnson-Smithsonian Deep-Sea Expedition to the Puerto Rican Deep-Three New Amphi-
pods. By Clarence R. Shoemaker. (Publication 3246.) Pp. 6. Vol 90d, No. 13 : Reports on the Collections obtained by the First Johnson91, No. 13: Reports on the Collections obtained by the First JohnsonSmithsonian Deep-Sea Expedition to the Puerto Rican Deep-A New
Genus of Brittlestars from Puerto Rico. By Austin H. Clark. (PubliGenus of Brittlestars from Puerto Rico. By Austin H. Clark. (Publication 3248.) Pp. 3+1 plate. Vol. 91, No. 14: Reports on the Collections obtained by the First Johnson-Smithsonian Deep-Sea Expe-
dition to the Puerto Rican Deep-A New Starfish from Puerto Rico. dition to the Puerto Rican Deep-A New Starfish from Puerto Ríco.
By Austin $\mathbf{H}$. Clark. (Publication 3249 .) Pp. $3+1$ plate. (Washington, By Austin H. Clark. (Publication

Union of South Africa: Department of Mines. Geological Series, Bulletin No. 1: The Witwatersrand System in the KlerksdorpVentersdorp Area ; a Preliminary Report. By Dr. Louis T. Nel. Pp. $32+2$ plates. 18. Geological Series, Bulletin No. 2: The Andalusite Sands of the Western Transvaal. By F. C. Partridge. Pp. 16. 6d. (Pretorla : Government Printer.)

Bulletin of the Michigan College of Mining and Technology. New Series, Vol. 7, No. 3: General Information for the Year 1934-1935. Pp. 153. (Houghton, Mich.)

Journal of the Faculty of Science, Imperial University of Tokyo. Section 1: Mathematics, Astronomy, Physics, Chemistry. Vol. 2, Part 10: Normenresttheorie galoisscher Zahlkörper mit Anwendungen auf Führer und Diskriminante abelscher Zahlkörper. Von Helmut Hasse. Pp. 477-498. 40 sen. Section 3 : Botany. Vol. 4, Part 3: Anatomical Studies on some Leguminous Leaves with Special Reference to the Vascular System in Petioles and Rachises. By Shunji Ltd.)

\section{Catalogues}

Africana : a Catalogue of Books, Maps and Pietures. (1934, No. 2.) Pp. 26. (London: Francis Edwards, Ltd.)

Catalogue de Livres anciens et modernes rares ou curienx relatifs à l'Orient. (No. 27.) Pp. 403-472. (Paris: Libr. Adrien-Maisonneuve.) Photography as an Aid to Scientifle Work. Pp. 8. (Ilford: Ilford, Ltd.)

B.D.H. Chlorotex Outfit for Determination of Free Chlorine in Swimming Pools and Drinking Water. Pp. 4. Acriflavine, Euflavine and Proflavine. Pp. 20. (London: The British Drug Houses, Ltd.) 